\title{
KARAKTERISTIK ORGANOLEPTIK DODOL UBI JALAR (Ipomoea batatas L.) TERHADAP DODOL BUAH-BUAHAN
}

\author{
Organoleptic Characteristics Dodol Products From Sweet Potato (Ipomoea batatas L.) \\ Against Dodol Fruits \\ Deny Utomo ${ }^{1)}$ \\ ${ }^{1}$ Staf Pengajar Prodi Ilmu dan Teknologi Pangan, Fakultas Pertanian, Universitas Yudharta \\ denyut369@gmail.com
}

\begin{abstract}
Sweet potato is one of the most important economic plants in the world, because it is rich in antioxidants. Processing sweet potatoes into dodol can increase the economic value of plants to food security, nutrition, increase in income and increase the welfare of farmers The purpose of this study was to determine the organoleptic characteristics of dodol products in three flavors. Organoleptic test using the Friedman Test with $\alpha=$ 0.05 and determining the best treatment using the index of effectiveness. The results showed that the best organoleptic test was obtained from sweet potato dodol products with a product value of 0.610 with a mean value of panelists' preference for taste of 4.40; color of 3.92 and aroma of 2.48 .
\end{abstract}

Key words: dodol of sweet potato, dodol of fruits

\begin{abstract}
ABSTRAK
Ubi jalar merupakan salah satu yang paling penting tanaman ekonomi di dunia, karena kaya akan antioksidan. Pengolahan ubi jalar menjadi dodol dapat menambah nilai ekonomis tanaman terhadap ketahanan pangan, gizi, peningkatan pendapatan dan peningkatan kesejahteraan petani Tujuan dari penelitian ini adalah untuk mengetahui karakteristik organoleptik terhadap produk dodol pada tiga rasa. Uji organoleptik menggunakan Uji Friedman dengan $\alpha=0,05$ dan penentuan perlakuan terbaik menggunakan indek efektifitas. Hasil penelitian menunjukkan bahwa uji organoleptik terbaik diperoleh dari produk dodol ubi jalar dengan nilai produk sebesar 0,610 dengan rerata nilai tingkat kesukaan panelis terhadap rasa sebesar 4,40; warna sebesar 3,92 dan aroma 2,48.
\end{abstract}

Kata kunci: dodol ubi jalar, dodol buah-buahan

\section{PENDAHULUAN}

Ubi jalar (Ipomoea batatas L.) merupakan salah satu yang paling penting tanaman ekonomi di dunia (BovellBenjamin, 2007). Ubi jalar adalah ketujuh tanaman pangan yang paling penting di dunia setelah gandum, beras, jagung, kentang, barley dan singkong (Lin et al., 2007; Sivakumar et al. 2008). Ubi jalar merupakan salah satu tanaman pokok utama dunia yang sangat penting dalam mengurangi masalah utama seperti kekurangan gizi, kerawanan pangan, konsekuensi dari kekeringan dan teknologi pertanian yang terbatas (Laurie et al., 2012).
Ubi jalar kaya akan pati, gula, vitamin $\mathrm{C}$, provitamin $\mathrm{A}$, zat besi dan mineral. Beberapa varietas ubi jalar mengandung pigmen berwarna: b-karoten, antosianin (Panda et al. 2009; Burri, 2011) dan sebagai antioksidan memiliki beberapa atribut fisiologis seperti antioxidation, antikanker, anti immunodilation dan perlindungan terhadap katarak, degenerasi otot dan luka hati (Sivakumar et al. 2010). Karotenoid dalam ubi jalar sangat penting untuk kesehatan manusia karena kemampuan mereka untuk meningkatkan sistem kekebalan tubuh, dan untuk menjaga kesehatan mata dan penglihatan (Montrone 
et al., 2009). Nilai gizi yang tinggi pqada ubi jalar membuat daya tarik tersendiri bagi petani dan masyarakat (Omoare et al., 2014), sehingga dapat dijadikan sebagai bahan makanan (Steed dan Truong, 2008). Pengolahah ubi jalar menjadi produk olahan dapat menambah nilai tanaman untuk berkontribusi signifikan terhadap ketahanan pangan, gizi, peningkatan pendapatan dan ditingkatkan mata pencaharian bagi petani (Omoare et al., 2014).

Selama ini ubi jalar di Desa Wringinsongo Kabupaten Malang hanya dimanfaatkan dalam bentuk segar (belum diolah) dengan harga jual yang murah sebesar Rp. 300,-/kg dari harga normal (Rp. $1.000 / \mathrm{kg}$ ), bahkan jika panen raya banyak yang terbuang dengan percuma karena tidak ada yang mau membeli. Hal ini terjadi karena ketidak pahaman masayarakat setempat tentang jenis produk lain yang dapat dihasilkan dari bahan baku ubi jalar, masyarakat juga belum memahami teknologi sederhana apa yang dapat diaplikasikan pada ubi jalar yang mereka miliki. Masyarakat masih beranggapan bahwa ubi jalar hanya bisa dijual dalam bentuk segar (belum diolah). Padahal hanya dengan sentuhan teknologi yang sederhana ubi jalar afkir akan menjadi produk olahan yang bernilai tinggi dibandingkan dengan menjual dalam bentuk segar. Salah satunya adalah mengolah ubi jalar menjadi dodol. Menurut Utomo et al. (2014) dan Novia et al. (2015) menyatakan bahwa cara pembuatan dodol sangatlah mudah, peralatan yang digunakan juga sederhana serta dapat pada industri skala rumah tangga.

Pengembangan produk dodol dengan subtitusi buah mangga pernah dikembangkan oleh Novia et al. (2015) serta layak untuk dikembangkan. Utomo et al. (2015) menyatakan dodol dengan subtitusi apel sangat digemari masyarakat dan dapat bersaing dengan produk dodol yang berededar di pasaran.

Hasil survei dilapangan menemukan harga jual ubi jalar normal Rp.1000,-/kg sampai Rp. 2.000,-/kg, sedangkan harga ubi jalar afkir Rp. 300,-/kg. Jika panen raya, maka jumlah ubi jalar semakin meningkat sebesar 10-15 ton dengan ubi jalar afkir sebesar $10 \%$ ( $1-1,5$ ton) dan kadang tidak laku dalam bentuk segar (belum diolah), bahkan ditemukan banyak jumlah ubi jalar afkir yang terbuang percuma. Ditinjau dari aspek budaya masyarakat setempat, banyaknya ubi jalar afkir yang tidak terjual atau terjual murah sangat dipengaruhi oleh kebiasaan dari petani pendahulunya dan belum adanya sarana prasarana yang memadai dalam mengakses informasi secara cepat.

Pemanfaatan ubi jalar melalui diversifikasi menjadi produk dodol bertujuan untuk meningkatkan nilai ekonomis dari ubi jalar dan produk dodol ini merupakan makan camilan yang harga terjangkau di masayarakat serta menyehatkan.

\section{BAHAN DAN METODE}

\section{Bahan}

Bahan yang digunakan dalam penelitian ini adalah santan kelapa, gula, garam, margarine, tepung ketan, ubi jalar, mangga, dan apel.

\section{Alat}

Alat-alat yang digunakan dalam penelitian ini meliputi, pemarut kelapa, sealer, dandang, kompor, pisau, talenan, sutil, bak penampungan bahan, wajan, sendok pengaduk, nampan cetakan, sepet, dan plastik kemasan

\section{Rancangan Penelitian}

Rancangan penelitian yang digunakan dalam penelitian ini adalah produk dodol ubi jalar dengan dodol mangga serta apel; D1 = dodol ubi jalar, D2 = dodol buah apel, D3 = dodol buah mangga.

\section{Pengamatan}

Pengamatan dilakukan terhadap tiga produk dodol ubi jalar dengan tiga rasa (warna, rasa dan aroma) dari 25 panelis yang tidak terlatih. 


\section{Analisis Data}

Data hasil uji organoleptik dianalisis dengan metode statistik non parametrik menggunakan Uji Friedman dengan $\alpha=$ 0,05, sedangkan perlakuan terbaik menggunakan indek efektifitas.

\section{HASIL DAN PEMBAHASAN \\ Rasa}

Hasil uji organoleptik menyajikan bahwa rerata ranking kesukaan panelis terhadap rasa dari produk dodol ubi jalar terhadap dodol buah mangga serta apel berkisar antara 2,08-4,40. Semakin tinggi rerata ranking kesukaan panelis, maka tingkat kesukaan panelis terhadap rasa semakin besar. Tabel 1 memperlihatkan rerata ranking tingkat kesukaan panelis terhadap rasa.

Tabel 1. Rerata tingkat kesukaan panelis terhadap rasa

\begin{tabular}{lc}
\hline \multicolumn{1}{c}{ Produk Dodol } & Rerata \\
\hline dodol ubi jalar (D1) & 4,40 \\
dodol buah apel (D2) & 2,52 \\
dodol buah mangga (D3) & 2,08 \\
\hline
\end{tabular}

Tabel 1 memperlihatkan rerata nilai kesukaan panelis terhadap rasa pada berbagai produk dodol dengan nilai terendah sebesar 2,08 didapatkan dari dodol buah mangga. Nilai tertinggi tingkat kesukaan panelis terhadap rasa sebesar 4,40 didapatkan dari dodol ubi jalar.

Hasil analisis Uji Friedman $(\alpha=0,05)$ berdasarkan uji perbandingan pada berbagai produk dodol memberikan pengaruh nyata. Kombinasi perlakuan terbaik tingkat kesukaan panelis terhadap rasa diperoleh dari produk dodol ubi jalar. Menurut panelis dodol ubi jalar mempunyai rasa yang lebih lembut dan manis serta sangat digemari oleh panelis.

\section{Warna}

Hasil uji organoleptik memperlihatkan bahwa rerata kesukaan panelis terhadap warna dari produk dodol ubi jalar terhadap dodol buah mangga serta apel berkisar antara 2,2-3,92. Semakin tinggi rerata ranking kesukaan panelis, maka tingkat kesukaan panelis terhadap warna semakin besar. Tabel 2 memperlihatkan rerata ranking tingkat kesukaan panelis terhadap warna.

Tabel 2. Rerata tingkat kesukaan panelis terhadap warna

\begin{tabular}{lc}
\hline \multicolumn{1}{c}{ Produk Dodol } & Rerata \\
\hline dodol ubi jalar (D1) & 3,92 \\
dodol buah apel (D2) & 2,84 \\
dodol buah mangga (D3) & 2,2 \\
\hline
\end{tabular}

Tabel 2 memperlihatkan rerata nilai kesukaan panelis terhadap warna pada produk dodol ubi jalar terhadap dodol buah mangga serta apel mempunyai nilai terendah sebesar 2,2 dari produk dodol buah mangga. Nilai tertinggi tingkat kesukaan panelis terhadap warna sebesar 3,92 didapatkan dari dodol ubi jalar.

Hasil analisis Uji Friedman $(\alpha=0,05)$ berdasarkan uji perbandingan pada berbagai kombinasi perlakuan pada rasa memberikan pengaruh nyata terhadap rerata kesukaan warna terhadap kombinasi perlakuan stik biji beton berbagai rasa. Kombinasi perlakuan terbaik tingkat kesukaan panelis terhadap warna diperoleh dari produk dodol ubi jalar, warna yang ditimbulkan oleh produk ubi jalar ini sangat menarik yaitu keunguan.

\section{Aroma}

Hasil uji organoleptik menyajikan bahwa rerata ranking kesukaan panelis terhadap aroma dari produk dodol ubi jalar terhadap dodol buah mangga serta apel berkisar antara 2,48-4,12. Semakin tinggi rerata ranking kesukaan panelis, maka tingkat kesukaan panelis terhadap aroma semakin besar. Tabel 3 memperlihatkan rerata ranking tingkat kesukaan panelis terhadap aroma.

Tabel 3. Rerata tingkat kesukaan panelis terhadap aroma

\begin{tabular}{lc}
\hline \multicolumn{1}{c}{ Produk Dodol } & Rerata \\
\hline dodol ubi jalar (D1) & 2,48 \\
dodol buah apel (D2) & 4,12
\end{tabular}


dodol buah mangga (D3)

2,92

Tabel 3 memperlihatkan rerata nilai kesukaan panelis terhadap aroma pada berbagai produk dodol dengan nilai terendah sebesar 2,48 dari dodol ubi jalar. Nilai tertinggi tingkat kesukaan panelis terhadap aroma sebesar 4,12 didapatkan dari dodol buah apel.

Hasil analisis Uji Friedman $(\alpha=0,05)$ berdasarkan uji perbandingan pada berbagai produk dodol memberikan pengaruh nyata. Kombinasi perlakuan terbaik tingkat kesukaan panelis terhadap aroma diperoleh dari dodol buah apel. Menurut panelis dodol buah apel memiliki aroma yang khas dan harum.

\section{Pemilihan Perlakuan Terbaik}

Pemilihan perlakuan terbaik dodol ubi jalar terhadap dodol buah mangga serta apel dilakukan dengan menggunakan metode indeks efektivitas. Hasil uji penentuan kombinasi perlakuan terbaik diperlihatkan pada Tabel 4.

Tabel 4. Nilai produk perlakuan terbaik

\begin{tabular}{lcccc}
\hline $\begin{array}{c}\text { Produk } \\
\text { Dodol }\end{array}$ & Rasa & Warna & Aroma & $\begin{array}{c}\text { Nilai } \\
\text { Produk }\end{array}$ \\
\hline $\begin{array}{l}\text { dodol } \\
\text { ubi jalar } \\
\text { (D1) }\end{array}$ & $\mathbf{4 , 4 0}$ & $\mathbf{3 , 9 2}$ & $\mathbf{2 , 4 8}$ & $\mathbf{0 . 6 1 0 *}$ \\
$\begin{array}{l}\text { dodol } \\
\text { buah }\end{array}$ & 2,52 & 2,84 & 4,12 & 0.570 \\
apel \\
$\begin{array}{l}\text { (D2) } \\
\text { dodol }\end{array}$ & & & & \\
$\begin{array}{l}\text { buah } \\
\text { mangga } \\
\text { (D3) }\end{array}$ & 2,08 & 2,2 & 2,92 & 0.105 \\
\hline *=Perlakuan terbaik & & & \\
\hline
\end{tabular}

Tabel 4 memperlihatkan hasil uji perlakuan terbaik didapatkan dari dodol ubi jalar dengan nilai produk sebesar 0,610 dengan karakteristik sebagai berikut: rerata nilai tingkat kesukaan panelis terhadap rasa sebesar 4,40; warna sebesar 3,92 dan aroma 2,48 .

\section{KESIMPULAN}

Karakteristik organoleptik terbaik diperoleh dari produk dodol ubi jalar dengan nilai produk sebesar 0,610 dengan rerata nilai tingkat kesukaan panelis terhadap rasa sebesar 4,40; warna sebesar 3,92 dan aroma 2,48 .

\section{UCAPAN TERIMA KASIH}

Penulis mengucapkan terima kasih kepada seluruh pihak yang telah membantu dalam pelaksanaan kegiatan PKM dan seluruh pihak yang telah membantu dalam penelitian ini terutama kepada Universitas Yudharta Pasuruan.

\section{DAFTAR PUSTAKA}

Bovell-Benjamin, A.C., (2007). Sweet potato: a review of its past, present, and future role in human nutrition. Advance Food Nutrition Research 52: $1-59$.

Burri, B. J. (2011). Evaluating sweet potato as an intervention food to prevent vitamin A deficiency. Comprehensive Reviews in Food Science and Food Safety 10(2): 118-130.

Laurie, S. M., Van Jaarsveld, P. J., Faber, M., Philpott, M. F. \& Labuschagne, M. T. (2012). Trans- $\beta$-carotene, selected mineral content and potential nutritional contribution of 12 sweetpotato varieties. Journal of Food Composition and Analysis 27(2): 151159.

Lin, K.H., Lai, Y.C., Chang, K.Y., Chen, Y.F., Hwang, S.Y. \& Lo, H.F., (2007). Improving breeding efficiency for quality and yield of sweet potato. Botanical Study 48: 283-292.

Montrone, M., Martorelli, D., Rosato, A. \& Dolcetti, R. (2009). Retinoids as critical modulators of immune functions: new therapeutic perspectives for old compounds. Endocrine, Metabolic \& Immune Disorders-Drug Targets (Formerly Current Drug Targets-Immune, Endocrine \& Metabolic Disorders) 9(2): 113-131. 
Novia, C., Syaiful \& Utomo, D. (2015). Diversifikasi mangga off grade menjadi Selai dan dodol. Teknologi Pangan 6(2) : 76-79.

Omoare, A. M., Fakoya, E. O., Fapojuwo, O. E. \& Oyediran, W. O. (2014). Awareness of value addition of sweet potato (Ipomoea batatas (L.) Lam) in Osun State, Nigeria. World Academy of Science, Engineering and Technology, International Journal of Biological, Agricultural, Biomolecular, Biotechnological Engineering 8(1): 20-24.

Panda, S. H., Naskar, S. K., Sivakumar, P. S. \& Ray, R. C. (2009). Lactic acid fermentation of anthocyanin-rich sweet potato (Ipomoea batatas L.) into lacto-juice. International Journal of Food Science \& Technology 44(2): 288-296.
Sivakumar, P. S., Panda, S. H., Ray, R. C., Naskar, S. K. \& Bharathi, L. K. (2010). Consumer acceptance of lactic acid-fermented sweet potato pickle. Journal of sensory studies 25(5): 706719.

Sivakumar, P. S., Pradhan, D. C., Das, S. N. \& Sivaramane, N. (2008). Analysis of structural change in area and productivity of sweet potato in Orissa. J. Root Crops 34: 181-187.

Steed, L.E., Truong, V.D., (2008). Anthocyanin content, antioxidant activity, and selected physical properties of flowable purple-fleshed sweet potato purees. Journal of Science 73: 215-221.

Utomo, D., Wahyuni, R. \& Novia, C. (2014). Diversifikasi produk olahan apel manalagi kualitas afkir menjadi selai dan dodol. Jurnal Agrika 8(2) : 211-217. 